\title{
REACTIVITY STUDIES OF URANIUM OXIDES
}

\author{
by
}

Dale A. Vaughan

J. Robert Bridge

Charles M. Schwartz

July 9, 1957

BATTELLE MEMORIAL INSTITUTE

505 King Avenue

Columbus 1, Ohio 


\section{DISCLAIMER}

This report was prepared as an account of work sponsored by an agency of the United States Government. Neither the United States Government nor any agency Thereof, nor any of their employees, makes any warranty, express or implied, or assumes any legal liability or responsibility for the accuracy, completeness, or usefulness of any information, apparatus, product, or process disclosed, or represents that its use would not infringe privately owned rights. Reference herein to any specific commercial product, process, or service by trade name, trademark, manufacturer, or otherwise does not necessarily constitute or imply its endorsement, recommendation, or favoring by the United States Government or any agency thereof. The views and opinions of authors expressed herein do not necessarily state or reflect those of the United States Government or any agency thereof. 


\section{DISCLAIMER}

Portions of this document may be illegible in electronic image products. Images are produced from the best available original document. 
TABLE OF CONTENTS

$\underline{\text { Page }}$

ABSTRACT . . . . . . . . . . . . . . . . . . . . . . . . . .

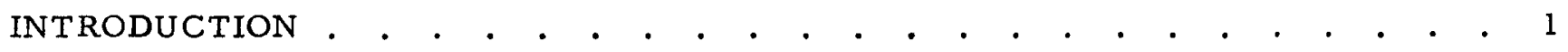

EXPERIMENTAL WORK . . . . . . . . . . . . . . . . . . ..

Decomposition of Uranyl Nitrate Hexahydrate . . . . . . . . . . . 2

$\mathrm{UO}_{3}$ Analysis and Reactivity Measurement . . . . . . . . . . . $\quad 2$

$\mathrm{UO}_{2}$ Analysis and Reactivity Measurement . . . . . . . . . . . .6

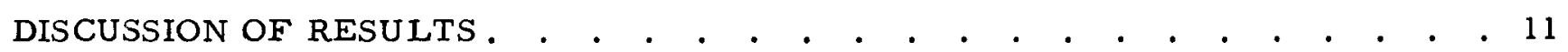

ACKNOWLEDGMENT • . . . . . . . . . . . . . . . . . . . . . . . 13

REFERENCES . . . . . . . . . . . . . . . . . . . . . . . . . . . 13 


\section{REACTIVITY STUDIES OF URANIUM OXIDES}

by

Dale A. Vaughn, J. Robert Bridge, and Charles M. Schwartz

One amorphous and three crystalline polymorphic modifications of $\mathrm{UO}_{3}$ have been prepared by pyrolysis of uranyl nitrate hexahydrate. The hydration reactivity of $\mathrm{UO}_{3}$ appears to be a function of its residual nitrogen content which is, in turn, dependent on the method, time, and temperature of denitration. Amorphous $\mathrm{UO}_{3}$ is more reactive than crystalline $\mathrm{UO}_{3}$.

The initial oxidation reactivity (the oxygen sorption in 1 day at room temperature) of $\mathrm{UO}_{2}$ varies with the method of preparation of the $\mathrm{UO}_{3}$. The average oxidation rate of $\mathrm{UO}_{2}$ after the first day decreases with increasing nitrogen content of the $\mathrm{UO}_{3}$ from which the $\mathrm{UO}_{2}$ was made. If soluble nitrates are removed from $\mathrm{UO}_{3}$ by water leaching prior to reduction, the final reoxidation reactivity of the $\mathrm{UO}_{2}$ is increased by a factor of 10. Hydration and dehydration of amorphous $\mathrm{UO}_{3}$, without leaching, decrease the final reoxidation reactivity of the subsequent $\mathrm{UO}_{2}$ by a factor of $10 . \mathrm{UO}_{2}$ made from amorphous $\mathrm{UO}_{3}$ has a higher reoxidation reactivity than when made from crystalline $\mathrm{UO}_{3}$ of the same nitrogen content.

\section{INTRODUCTION}

Production of uranium metal requires several steps in processing high-purity uranium salts (pyrolysis of $\mathrm{UO}_{2}\left(\mathrm{NO}_{3}\right)_{2} \cdot 6 \mathrm{H}_{2} \mathrm{O}$ to $\mathrm{UO}_{3}$, reduction of $\mathrm{UO}_{3}$ to $\mathrm{UO}_{2}$, and hydrofluorination of $\mathrm{UO}_{2}$ to $\mathrm{UF}_{4}$ ) before final reduction. The variables in each step are being investigated for their effect upon the subsequent product. This study of the structure, composition, and chemical reactivity of uranium trioxide was undertaken to determine the effects of these variables upon the reactivity of uranium dioxide made from various preparations of uranium trioxide. Chemical reactivity of $\mathrm{UO}_{3}$ was measured by the amount of water sorption at $30 \mathrm{C}$. As a measure of the reactivity of uranium dioxide, its reoxidation rate was determined on exposure to air at room temperature. A previous Battelle report(l) describes the process of thermal decomposition of uranyl nitrate hexahydrate, the end product in the uranium-ore-purification process. It was shown, in that report, that the several polymorphic forms of $\mathrm{UO}_{3}$, as described by Katz (2), can be produced by thermal decomposition of the nitrate. The sinterability of $\mathrm{UO}_{2}$ made from various polymorphic forms of $\mathrm{UO}_{3}$ was reported earlier (3). E. J. Barber (4) and workers at Mallinckrodt Chemical Works ${ }^{(5)}$ have shown that there are marked differences in the rate of hydrofluorination of $\mathrm{UO}_{2}$ made from various types of $\mathrm{UO}_{3}$.

In view of these results and the lack of information on the relationship among structure, composition, and reactivity of uranium trioxide, it was of interest to determine how these variables affect the reactivity of the two oxides, $\mathrm{UO}_{3}$ and $\mathrm{UO}_{2}$.

(1) References at end. 


\section{EXPERIMENTAL WORK}

\section{Decomposition of Uranyl Nitrate Hexahydrate}

Two general methods based upon previous work $(1)$ were employed in the pyrolytic decomposition of uranyl nitrate hexahydrate, one in which the nitrate melts during decomposition, and the other in which the nitrate decomposes without melting. The oxide obtained by the first method is crystalline, while that obtained by the latter is amorphous. Three crystalline forms of $\mathrm{UO}_{3}$ may be produced from the nitrate. Type III $\mathrm{UO}_{3}{ }^{*}$, the most common crystalline form, is produced when uranyl nitrate hexahydrate is heated in bulk quantities until the water and nitrogen oxides volatilize. Type II UO 3 is produced if a thin bed of the nitrate is heated rapidly to 450 or $500 \mathrm{C}$ or if a small batch $(60$ to $90 \mathrm{~g})$ of nitrate, to which $1 \mathrm{w} / 0$ acetic acid has been added, is heated to $450 \mathrm{C}$. The latter method is more reproducible. Type $\mathrm{I} \mathrm{UO}_{3}$ is produced by addition of ethyl alcohol to uranyl nitrate hexahydrate followed by flash denitration at $425 \mathrm{C}$.

An amorphous form of $\mathrm{UO}_{3}$ is obtained when decomposition of uranyl nitrate hexahydrate is accomplished stepwise as described in BMI-1110. (1) The water of hydration is removed first, then the anhydrous nitrate is decomposed. Two methods of water removal were employed, one in which the nitrate was vacuum dried and further heated at increasing temperatures to $150 \mathrm{C}$ and the other in which hot gas, at atmospheric pressure, dried a thin layer of nitrate as it was carried on a belt into a furnace for final denitration. Final denitration of the vacuum-dried nitrate was carried out in an open pot at various temperatures from 200 to $450 \mathrm{C}$.

$\mathrm{UO}_{3}$ Analysis and Reactivity Measurement

Since the final denitration temperature used in the production of $\mathrm{UO}_{3}$ may not yield completely decomposed nitrate, analyses were made for retention of nitrogen in the $\mathrm{UO}_{3}$ structure. Water may also be retained in the $\mathrm{UO}_{3}$ structure. Analysis for water may be obtained by difference, assuming the nitrogen to be present as nitrate. For all $\mathrm{UO}_{3}$ preparations, the structure type was determined by powder X-ray diffraction, using filtered iron radiation. The per cent conversion of the nitrate to $\mathrm{UO}_{3}$ was determined by weight change on ignition to $\mathrm{U}_{3} \mathrm{O}_{8}$ at $750 \mathrm{C}$. Residual nitrogen content of $\mathrm{UO}_{3}$ was obtained by the Kjeldahl method. The results of these analyses are given in Table 1. The last column in Table 1 gives the hydration reactivity in terms of equilibrium water content of the various preparations on exposure to water-saturated air at $30 \mathrm{C}$. Type I UO 3 has not been prepared in sufficient quantity for hydration-reactivity studies or for nitrogen analyses.

The results on Type III and amorphous $\mathrm{UO}_{3}$ indicate two systematic trends. The nitrogen content of $\mathrm{UO}_{3}$ decreases with increasing temperature of denitration, as shown in Figure 1, while the hydration reactivity of $\mathrm{UO}_{3}$, presented graphically in Figure 2 , increases with nitrogen content. The reactivity of amorphous oxide is significantly greater than that of Type III oxide at corresponding low nitrogen contents, $0.1 \mathrm{w} / \mathrm{o}$. $\mathrm{X}$-ray diffraction analyses of the hydrated samples show that amorphous $\mathrm{UO}_{3}$ hydrates to the dihydrate structure, while Type III UO3 hydrates to the monohydrate structure.

\footnotetext{
- The structure types of $\mathrm{UO}_{3}$ correspond to those described by Katz, Reference (2).
} 
TABLE 1. COMPARISON OF PERCENTAGE CONVERSION AND NITROGEN CONTENT OF UO 3 WITH FINAL DENITRATION TEMPERATURE AND HYDRATION REACTIVITY

\begin{tabular}{|c|c|c|c|c|c|c|}
\hline \multirow[b]{2}{*}{ Starting Material } & \multirow{2}{*}{$\begin{array}{c}\text { Type } \\
\text { of } \mathrm{UO}_{3} \\
\end{array}$} & \multicolumn{2}{|c|}{ Denitration } & \multirow{2}{*}{$\begin{array}{l}\text { Conversion, } \\
\text { per cent } \mathrm{UO}_{3}\end{array}$} & \multirow[b]{2}{*}{ Nitrogen, w/o } & \multirow{2}{*}{$\begin{array}{c}\text { Hydration } \\
\text { w/o } \mathrm{H}_{2} \mathrm{O}\end{array}$} \\
\hline & & Temperature, C & Time, hr & & & \\
\hline UNH & III & 200 & 4 & 98.98 & .24 & 15.84 \\
\hline UNH & III & 250 & 4 & 94.50 & .12 & - \\
\hline UNH & III & 300 & 4 & 99.59 & .104 & 8.89 \\
\hline UNH & III & 325 & 4 & 99.35 & - & - \\
\hline UNH & III & 350 & 4 & 99.58 & .101 & - \\
\hline UNH & III & 400 & 4 & 99.65 & .098 & 8.28 \\
\hline $\mathrm{UNH}$ & III & 425 & 2 & 99.36 & .075 & - \\
\hline $\mathrm{UNH}$ & III & 425 & 4 & 99.60 & - & - \\
\hline $\mathrm{UNH}$ & III & 450 & 4 & 99.66 & .058 & 8.38 \\
\hline UNH, moving-belt method & Amorphous & 350 & - & 97.87 & .24 & 16.30 \\
\hline UNH, moving-belt method & Amorphous & 400 & - & 98.97 & .064 & 13.44 \\
\hline UNH, moving-belt method & Amorphous & 425 & - & 98.88 & .032 & 12.44 \\
\hline UNH, moving-belt method & Amorphous & 450 & - & 99.08 & .02 & 12.50 \\
\hline $\mathrm{UNH}$, vacuum dried at $125 \mathrm{C}$ & Amorphous & 250 & 2 & 96.56 & - & 22.65 \\
\hline UNH, vacuum dried at $125 \mathrm{C}$ & Amorphous & 350 & 2 & 99.62 & - & - \\
\hline UNH, vacuum dried at $125 \mathrm{C}$ & Amorphous & 450 & 2 & 99.92 & .002 & - \\
\hline UNH, vacuum dried at $150 \mathrm{C}$ & Amorphous & 300 & 2 & 97.20 & .57 & 22.18 \\
\hline $\mathrm{UNH}$, vacuum dried at $150 \mathrm{C}$ & Amorphous & 300 & 4 & 99.27 & .13 & 15.21 \\
\hline UNH, vacuum dried at $150 \mathrm{C}$ & Amorphous & 300 & 8 & 99.38 & - & - \\
\hline UNH, vacuum dried at $150 \mathrm{C}$ & Amorphous & 400 & 4 & 99.72 & .01 & 13.16 \\
\hline UNH, + ethyl alcohol & I & 425 & $1 / 30$ & 96.55 & - & - \\
\hline $\mathrm{UNH}+0.6 \mathrm{w} / 0$ acetic acid & II & 425 & 4 & 99.32 & - & 10.85 \\
\hline $\mathrm{UNH}+1.0 \mathrm{w} / 0$ acetic acid & II & 450 & 4 & 99.56 & - & 11.00 \\
\hline
\end{tabular}




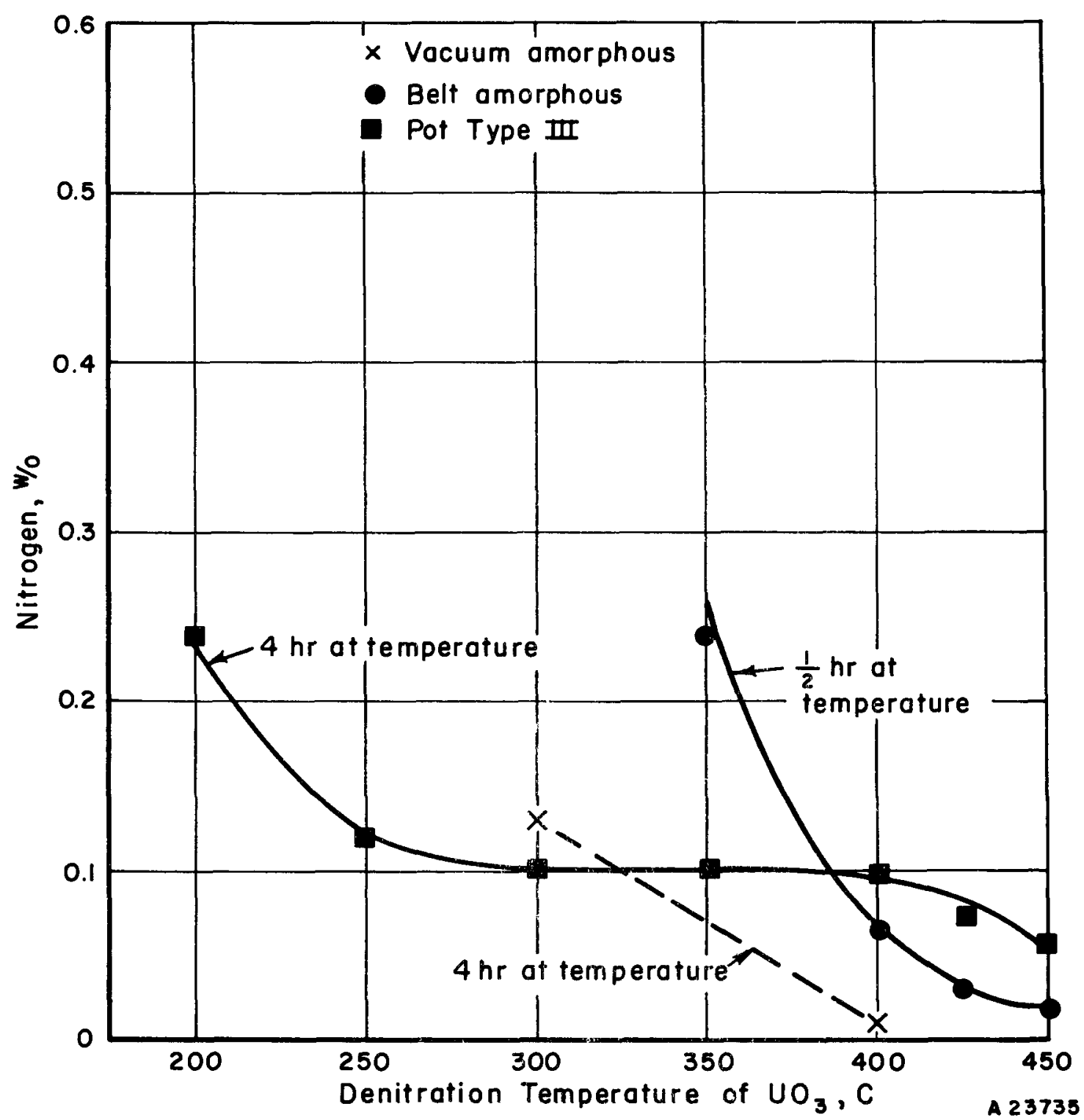

FIGURE 1. NITROGEN CONTENT OF UO 3 VERSUS TEMPERATURE OF DENITRATION 


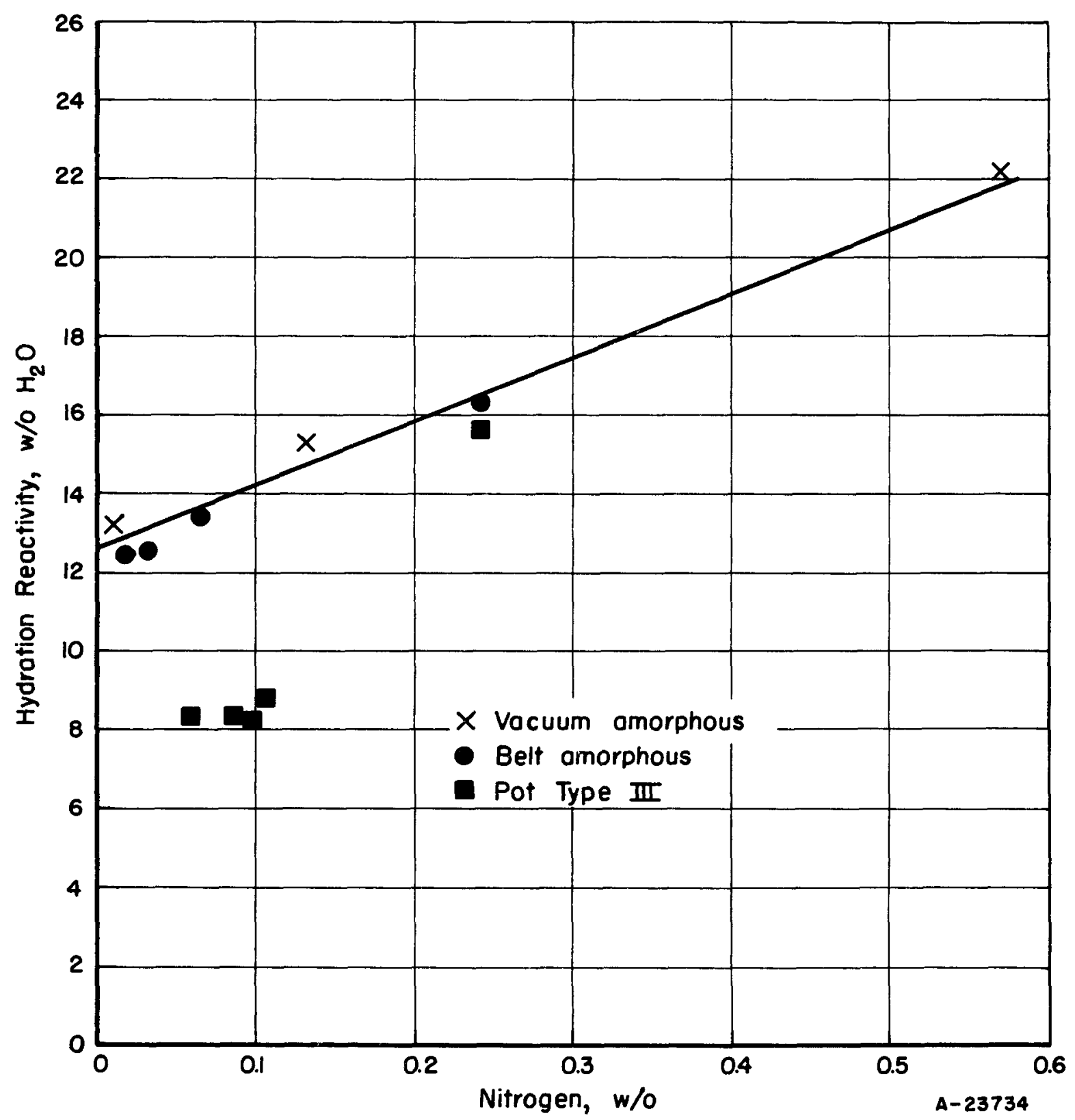

FIGURE 2. HYDRATION REACTIVITY VERSUS NITROGEN CONTENT 
These differences in the amount of hydration and in the structure of the hydrate phases suggest a difference in the free energy of the two forms of $\mathrm{UO}_{3}$.

Since the hydration reactivity is directly related to the nitrogen content for a given $\mathrm{UO}_{3}$ structure, removal of the residual nitrate nitrogen by water leaching was studied. Several $\mathrm{UO}_{3}$ preparations were leached with water until the filtrate was no longer colored. The insoluble portion was dried at $300 \mathrm{C}$ and analyzed in the same manner as the original preparation. The change in nitrogen content as a result of leaching is presented in Table 2. In order to differentiate between the effects of hydration and leaching, several samples were hydrated in such a way as to minimize removal of the soluble salts, dried at $300 \mathrm{C}$, and then analyzed for nitrogen content. The last column of Table 2 indicates that a significant amount of nitrogen remained in these samples. X-ray analyses showed that only amorphous $\mathrm{UO}_{3}$ was obtained from leached and dried $\mathrm{UO}_{3}$. Highnitrogen $\mathrm{UO}_{3}$, hydrated and dried, gave diffraction patterns of crystalline $\mathrm{UO}_{3}$, while the structure of low-nitrogen $\mathrm{UO}_{3}$ (whether crystalline or amorphous) was not changed by hydration and drying.

Only a limited investigation was made of the $\mathrm{UO}_{3}$ hydration reactivity after prior hydration and drying. It was observed that, if a structural change developed during the first cycle of hydrating and drying, the second hydration reactivity was different from the first, otherwise the hydration reactivity was not significantly different. No hydration-reactivity data were obtained on leached samples of $\mathrm{UO}_{3}$.

$\mathrm{UO}_{2}$ Analysis and Reactivity Measurement

The $\mathrm{UO}_{3}$ preparations discussed in the previous section were reduced to $\mathrm{UO}_{2}$, and the effects of the prior $\mathrm{UO}_{3}$ structure and composition upon the reactivity of the $\mathrm{UO}_{2}$ were investigated. Uranium trioxide, when exposed to hydrogen for $2 \mathrm{hr}$ at $600 \mathrm{C}$, is reduced to red $\mathrm{UO}_{2}$. In the present study, dry hydrogen was used to carry out reduction, and the $\mathrm{UO}_{2}$ was cooled to room temperature in hydrogen. Analysis of the oxygen content of the $\mathrm{UO}_{2}$ was obtained by weight change on ignition in air at $750 \mathrm{C}$. The as reduced oxide gave an oxygen-to-uranium ratio of nearly 2.00 before exposure to air. However, upon exposure to air, the oxide changed color, evolved heat, and the oxygento-uranium ratio increased. The amount of this increase in 1 day is presented in Table 3 for $\mathrm{UO}_{2}$ made from various preparations of $\mathrm{UO}_{3}$. The last two columns in Table 3 give the oxygen-to-uranium ratio of these $\mathrm{UO}_{2}$ preparations after storing at atmospheric temperature for more than 3 weeks. The average rate of change in the oxygen-to-uranium ratio during storage increases with decreasing nitrogen content for all methods of $\mathrm{UO}_{3}$ preparation, as shown in Figure 3. However, the magnitude of the change in oxygen-to-uranium ratio is greater for $\mathrm{UO}_{2}$ made from amorphous $\mathrm{UO}_{3}$ than for $\mathrm{UO}_{2}$ made from crystalline $\mathrm{UO}_{3}$ of the same nitrogen content. Thus, it seems that the reactivity of $\mathrm{UO}_{2}$ during storage is affected by both structure and composition of the $\mathrm{UO}_{3}$.

Since the reactivity of $\mathrm{UO}_{2}$ is influenced to a great extent by the nitrogen content for a given $\mathrm{UO}_{3}$ structure, the effect of nitrogen removal from $\mathrm{UO}_{3}$ on the reactivity of $\mathrm{UO}_{2}$ was investigated. The water-soluble nitrates in $\mathrm{UO}_{3}$ were leached out, as described in the previous section, before reduction to $\mathrm{UO}_{2}$. The $\mathrm{UO}_{2}$ reactivities for leached and unleached $\mathrm{UO}_{3}$ samples are given in Table 4. Except for two samples, the 
TABLE 2. COMPARISON OF NITROGEN CONTENT OF UO 3 PREPARATIONS BEFORE AND AFTER WATER LEACHING AND HYDRATING

\begin{tabular}{cccc}
\hline & & \multicolumn{3}{c}{ Nitrogen Content, w/o } \\
\cline { 2 - 4 } Type of UO 3 & Original Preparation & After Leaching(a) & After Hydrating(a) \\
\hline Amorphous & 0.24 & .005 & -- \\
Amorphous & 0.032 & .005 & -- \\
Amorphous & 0.13 & .005 & -- \\
Amorphous & 0.01 & .005 & -- \\
III & 0.24 & -- & .048 \\
III & 0.104 & .005 & .038 \\
III & 0.101 & .005 & -- \\
III & 0.098 & .005 & .037 \\
III & 0.058 & .005 & .027 \\
III & 0.111 & -- & .030 \\
III & 0.085 & -- & .037 \\
III & 0.103 & -- & .041 \\
III & 0.093 & -- & .039 \\
\hline
\end{tabular}

(a) The water of hydration was removed by drying at $300 \mathrm{C}$. This second heating of the samples reduces the nitrogen as shown in the last column. 
TABLE 3. CHANGE IN OXYGEN-TO-URANIUM RATIO OF UO 2 COMPARED WITH THE METHOD OF PREPARATION AND NITROGEN CONTENT OF UO

\begin{tabular}{|c|c|c|c|c|c|c|c|}
\hline \multirow[b]{2}{*}{$\begin{array}{c}\text { Preparation } \\
\text { Method }\end{array}$} & \multicolumn{3}{|c|}{$\mathrm{UO}_{3}$} & \multicolumn{3}{|c|}{ Oxygen-to-Uranıum Ratio of $\mathrm{UO}_{2}$} & \multirow{2}{*}{$\begin{array}{l}\text { Rate of } \\
\text { Reoxidation } \\
\text { in O/U Per } \\
\text { Day } 10^{3}\end{array}$} \\
\hline & $\begin{array}{c}\text { Denitration } \\
\text { Temperature, } C\end{array}$ & Type & $\begin{array}{c}\text { Content, } \\
\text { w/o }\end{array}$ & $\begin{array}{ll} & \text { In } \\
\text { l Day }\end{array}$ & $\begin{array}{l}\text { After } \\
\text { X Days }\end{array}$ & $\begin{array}{l}\text { Time, } \\
\text { days }\end{array}$ & \\
\hline Belt amorphous & 350 & Amorphous & 0.24 & 2.259 & 2.341 & 21 & 3.8 \\
\hline Belt amorphous & 400 & Amorphous & 0.064 & 2.108 & 2.137 & 21 & 1.4 \\
\hline Belt amorphous & 425 & Amorphous & 0.032 & 2.128 & 2.254 & 47 & 2.7 \\
\hline Belt amorphous & 450 & Amorphous & 0.02 & 2.093 & 2.185 & 21 & 4.2 \\
\hline Vacuum amorphous & 250 & Amorphous & -- & 2.166 & 2.323 & 23 & 6.2 \\
\hline Vacuum amorphous & 350 & Amorphous & - & 2.181 & 2.327 & 22 & 8.6 \\
\hline Vacuum amorphous & 450 & Amorphous & 0.002 & 2.203 & 2.357 & 20 & 7.7 \\
\hline Vacuum amorphous & 300 & Amorphous & 0.57 & 2.155 & 2.175 & 19 & 1.1 \\
\hline Vacuum amorphous & 300 & Amorphous & 0.13 & 2.166 & 2.263 & 21 & 4.6 \\
\hline Vacuum amorphous & 400 & Amorphous & 0.01 & 2.183 & 2.335 & 21 & 7.2 \\
\hline Pot & 200 & III & 0.24 & 2.037 & 2.047 & 28 & 0.36 \\
\hline Pot & 250 & III & 0.12 & 2.036 & 2.047 & 28 & 0.39 \\
\hline Pot & 300 & III & 0.104 & 2.039 & 2.044 & 28 & 0.18 \\
\hline Pot & 350 & III & 0.101 & 2.031 & 2.047 & 27 & 0.59 \\
\hline Pot & 400 & III & 0.098 & 2.041 & 2.048 & 27 & 0.26 \\
\hline Pot & 450 & III & 0.058 & 2.049 & 2.072 & 27 & 0.85 \\
\hline Pot & 250 & III & 0.111 & 2.045 & 2.050 & 22 & 0.23 \\
\hline Pot & 300 & III & 0.085 & 2.054 & 2.076 & 22 & 1.0 \\
\hline Pot & 350 & III & 0.103 & 2.037 & 2.055 & 21 & 0.85 \\
\hline Pot & 400 & III & 0.093 & 2.036 & 2.050 & 21 & 0.67 \\
\hline Pot & 425 & II & - & 2.069 & 2.125 & 21 & 2.7 \\
\hline Pot & 425 & I & - & 2.14ó & -- & - & -- \\
\hline
\end{tabular}




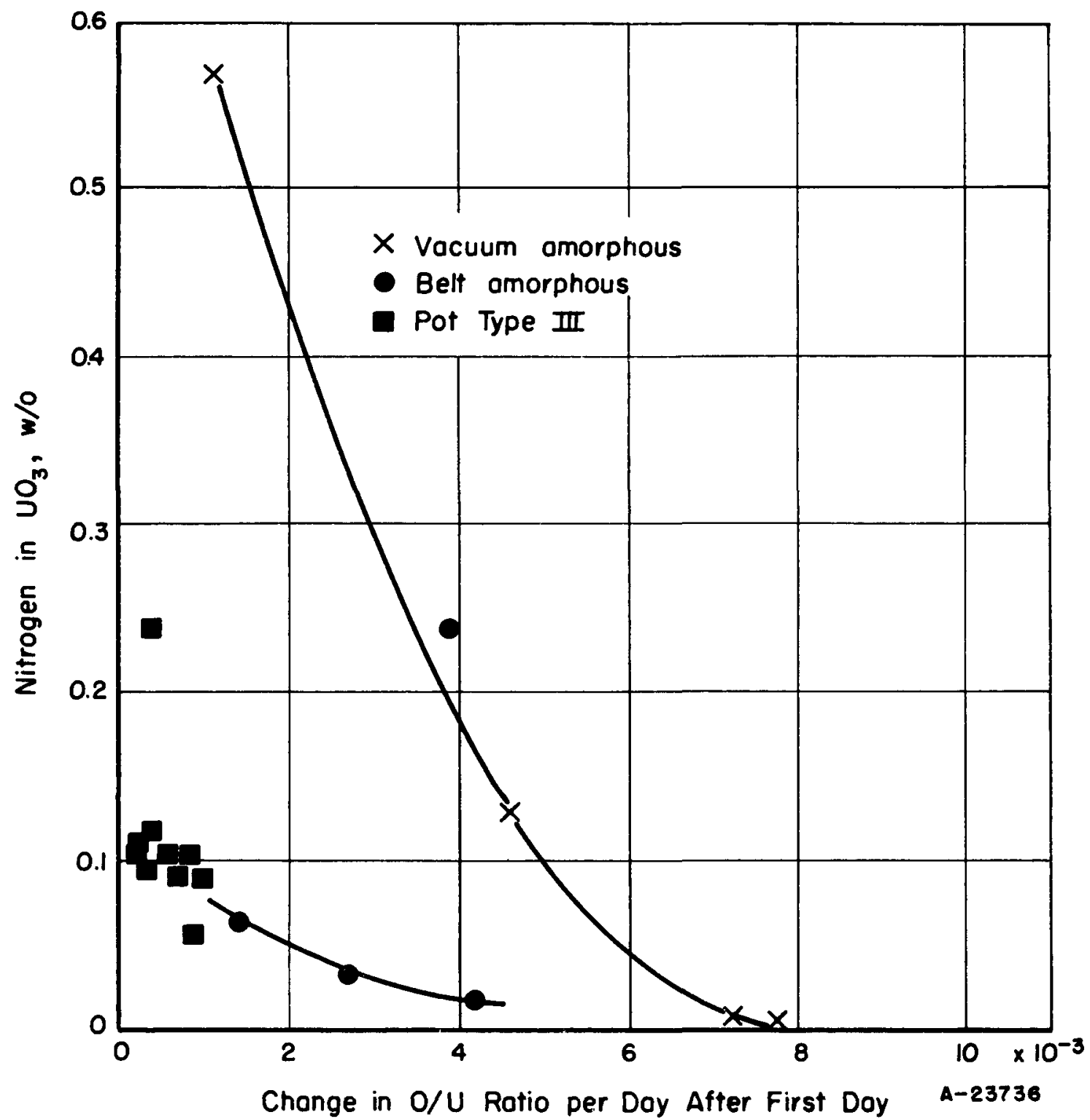

FIGURE 3. REACTIVITY OF UO 2 WITH TIME VERSUS NITROGEN CONTENT OF $\mathrm{UO}_{3}$ 
TABLE 4. EFFECT OF WATER LEACHING OF $\mathrm{UO}_{3}$ ON REACTIVITY OF $\mathrm{UO}_{2}$

\begin{tabular}{|c|c|c|c|c|c|c|c|c|c|}
\hline \multirow[b]{3}{*}{$\begin{array}{l}\text { Original } \\
\mathrm{UO}_{3} \text { Type }\end{array}$} & \multirow[b]{3}{*}{$\begin{array}{c}\text { Denitration } \\
\text { Temperature, C }\end{array}$} & \multicolumn{4}{|c|}{$\mathrm{UO}_{2}$ Made From Original $\mathrm{UO}_{3}$} & \multicolumn{4}{|c|}{$\mathrm{UO}_{2}$ Made From Leached $\mathrm{UO}_{3}(\mathrm{a})$} \\
\hline & & \multicolumn{2}{|c|}{$\begin{array}{c}\text { Oxygen-to- } \\
\text { Uranium Ratio }\end{array}$} & \multirow{2}{*}{$\begin{array}{c}\text { Storage } \\
\text { Time } \\
\text { days }\end{array}$} & \multirow{2}{*}{$\begin{array}{c}\text { Rate of } \\
\text { Reoxidation, } \\
\text { O/U per } \\
\text { day } \times 10^{3}\end{array}$} & \multicolumn{2}{|c|}{$\begin{array}{c}\text { Oxygen-to- } \\
\text { Uranium Ratio }\end{array}$} & \multirow{2}{*}{$\begin{array}{c}\text { Storage } \\
\text { Time, } \\
\text { days }\end{array}$} & \multirow{2}{*}{$\begin{array}{c}\text { Rate of } \\
\text { Reoxidation } \\
\text { O/U per } \\
\text { day } \times 10^{3}\end{array}$} \\
\hline & & $\begin{array}{ll}\text { In } \\
\text { I Day }\end{array}$ & $\begin{array}{c}\text { After } \\
\text { X Days }\end{array}$ & & & $\begin{array}{l}\text { In } \\
1 \text { Day }\end{array}$ & $\begin{array}{c}\text { After } \\
\text { X Days }\end{array}$ & & \\
\hline Vacuum amorphous & 250 & 2.166 & 2.323 & 23 & 6.8 & 2.116 & 2.230 & 21 & 5.4 \\
\hline Vacuum amorphous & 300 & 2.155 & 2. 175 & 18 & 1.1 & 2.089 & 2.179 & 45 & 2.0 \\
\hline Vacuum amorphous & 300 & 2.166 & 2.263 & 21 & 4.6 & 2.091 & 2.210 & 21 & 5.7 \\
\hline Vacuum amorphous & 400 & 2.183 & 2.335 & 21 & 7.2 & 2.081 & 2.166 & 21 & 4.0 \\
\hline Belt amorphous & 350 & 2.259 & 2.341 & 21 & 3.9 & 2.113 & 2.221 & 21 & 5.6 \\
\hline Belt amorphous & 425 & 2.128 & 2.254 & 47 & 2.7 & 2.104 & 2.238 & 21 & 6.4 \\
\hline $\mathrm{MCW}, \operatorname{III}(\mathrm{b})$ & -- & 2.047 & 2.072 & 58 & 0.43 & 2.048 & 2.085 & 48 & 0.77 \\
\hline $\mathrm{MCW}, \operatorname{III}(\mathrm{b})$ & - & 2.037 & 2.059 & 58 & 0.38 & 2.070 & 2.105 & 48 & 0.73 \\
\hline $\mathrm{MCW}, \operatorname{III}(\mathrm{b})$ & -- & 2.056 & 2.075 & 56 & 0.34 & 2.051 & 2.094 & 21 & 2.0 \\
\hline $\mathrm{MCW}, \operatorname{III}(\mathrm{b})$ & -- & 2.042 & 2.080 & 56 & 0.68 & 2.051 & 2.077 & 21 & 1.2 \\
\hline $\mathrm{MCW}, \operatorname{III}(\mathrm{b})$ & -- & 2.047 & 2.074 & 28 & 0.96 & 2.047 & 2.086 & 28 & 1.45 \\
\hline III & 300 & 2.039 & 2.044 & 28 & 0.18 & 2.043 & 2.109 & 21 & 3.1 \\
\hline III & 350 & 2.031 & 2.047 & 27 & 0.59 & 2.061 & 2.091 & 21 & 1.5 \\
\hline III & 400 & 2.041 & 2.048 & 27 & 0.26 & 2.057 & 2.073 & 21 & 1.7 \\
\hline III & 450 & 2.049 & 2.072 & 27 & 0.85 & 2.084 & 2.123 & 21 & 1.9 \\
\hline
\end{tabular}

(a) The leached samples of $\mathrm{UO}_{3}$ were dried at $300 \mathrm{C}$ before reduction to $\mathrm{UO}_{2}$.

(b) Mallinckrodt Chemical Works produced $\mathrm{UO}_{3}$. 
rate of change in the oxygen-to-uranium ratio of the $\mathrm{UO}_{2}$ increased as a result of leaching. However, leaching hydrates the $\mathrm{UO}_{3}$. Table 5 presents corresponding data on the reactivity of $\mathrm{UO}_{2}$ made from hydrated $\mathrm{UO}_{3}$ samples, in which leaching was not carried out. The $\mathrm{UO}_{2}$ reactivity decreased in all cases of $\mathrm{UO}_{2}$ made from amorphous $\mathrm{UO}_{3}$ but is increased for the $\mathrm{UO}_{2}$ made from Type III $\mathrm{UO}_{3}$.

Analyses for residual nitrogen by the $\mathrm{Kjeldahl}$ method were made on $\mathrm{UO}_{2}$ samples prepared from $\mathrm{UO}_{3}$ containing high and low nitrogen contents. These analyses revealed that less than $0.002 \mathrm{w} / \mathrm{o}$ nitrogen was retained through the reduction step.

\section{DISCUSSION OF RESULTS}

The results of this investigation on the reactivity of uranium oxides show that structural and compositional differences, resulting from methods of production, may be inherited and may influence the activity of materials in subsequent processing steps. Only a limited amount of study of this phenomenon in relation to the hydrofluorination and magnesium-reduction steps of uranium production has been done. However, studies carried out by Barber ${ }^{(4)}$ and at Mallinckrodt Chemical Works ${ }^{(5)}$ through the hydrofluorination step show a marked effect of $\mathrm{UO}_{3}$ structure upon the hydrofluorination reactivity of the $\mathrm{UO}_{2}$.

The present investigation revealed a marked difference in reoxidation reactivity of $\mathrm{UO}_{2}$ which could be related to the prior $\mathrm{UO}_{3}$ structure, as was exhibited in the hydrofluorination reactivity tests. In addition to the effect of prior structure, the higher the nitrogen content of the $\mathrm{UO}_{3}$ the lower was the reoxidation reactivity of the subsequent $\mathrm{UO}_{2}$, even though there was no evidence for retention of nitrogen in the $\mathrm{UO}_{2}$ structure. Assuming the Kjeldahl method of analysis is sensitive to all the nitrogen retained in the $\mathrm{UO}_{2}$ structure, the effect of nitrogen in $\mathrm{UO}_{3}$ on the reoxidation reactivity of $\mathrm{UO}_{2}$ must be related to the method of nitrogen removal during the reduction step. Fundamental investigations on the nature of bonding of impurity atoms in the oxides and on the pore structure of $\mathrm{UO}_{2}$ made from high-and low-nitrogen $\mathrm{UO}_{3}$ are necessary for a better understanding of uranium oxide chemistry. However, based upon the results of the present investigation, the following conclusions can be drawn concerning nitrogen retention in $\mathrm{UO}_{3}$ and the reoxidation reactivity of subs equent $\mathrm{UO}_{2}$.

(1) The residual nitrogen content of $\mathrm{UO}_{3}$ depends upon the time and temperature of denitration and the uranyl nitrate hexahydrate pyrolysis method.

(2) For open-pot pyrolysis methods, which result in Type III $\mathrm{UO}_{3}$, the residual nitrogen content of the oxide decreases rapidly from 200 to $250 \mathrm{C}$, does not change appreciably with temperature from 250 to $400 \mathrm{C}$, and decreases slowly with temperature above $400 \mathrm{C}$.

(3) For stepwise (water, then nitrogen oxide) pyrolysis methods which result in amorphous $\mathrm{UO}_{3}$, the residual nitrogen content decreases rapidly with temperature from 300 to $425 \mathrm{C}$.

(4) The nitrogen content of amorphous $\mathrm{UO}_{3}$ is higher than that of Type III $\mathrm{UO}_{3}$ for comparable times of denitration at $300 \mathrm{C}$, but less at $400 \mathrm{C}$ and above. 
TABLE 5. EFFECT OF HYDRATION OF UO 3 ON REACTIVITY OF UO 2

\begin{tabular}{|c|c|c|c|c|c|c|c|c|c|}
\hline \multirow[b]{3}{*}{$\begin{array}{c}\text { Original } \\
\mathrm{UO}_{3} \text { Type }\end{array}$} & \multirow[b]{3}{*}{$\begin{array}{c}\text { Denitration } \\
\text { Temperature, } \mathrm{C}\end{array}$} & \multicolumn{4}{|c|}{$\mathrm{UO}_{2}$ Made From Original $\mathrm{UO}_{3}$} & \multicolumn{4}{|c|}{$\mathrm{UO}_{2}$ Made From Hydrated $\mathrm{UO}_{3}(\mathrm{a})$} \\
\hline & & \multicolumn{2}{|c|}{$\begin{array}{l}\text { Oxygen-to- } \\
\text { Uranium Ratio }\end{array}$} & \multirow{2}{*}{$\begin{array}{c}\text { Storage } \\
\text { Time, } \\
\text { days }\end{array}$} & \multirow{2}{*}{$\begin{array}{c}\text { Rate of } \\
\text { Reoxidation, } \\
\text { O/U per } \\
\text { day } \times 10^{3}\end{array}$} & \multicolumn{2}{|c|}{$\begin{array}{l}\text { Oxygen-to- } \\
\text { Uranium Ratio }\end{array}$} & \multirow{2}{*}{$\begin{array}{c}\text { Storage } \\
\text { Time, } \\
\text { days }\end{array}$} & \multirow{2}{*}{$\begin{array}{c}\text { Rate of } \\
\text { Reoxidation, } \\
\text { O/U per } \\
\text { day } \times 10^{3}\end{array}$} \\
\hline & & $\begin{array}{ll} & \text { In } \\
1 \text { Day }\end{array}$ & $\begin{array}{l}\text { After } \\
\text { X Days }\end{array}$ & & & $\begin{array}{ll} & \text { In } \\
\text { l Day }\end{array}$ & $\begin{array}{c}\text { After } \\
\text { X Days }\end{array}$ & & \\
\hline $\begin{array}{l}125 \text {-vacuum } \\
\text { amorphous }\end{array}$ & 250 & 2.166 & 2.323 & 23 & 6.8 & 2.088 & 2.147 & 56 & 1.05 \\
\hline $\begin{array}{l}150 \text {-vacuum } \\
\text { amorphous }\end{array}$ & 300 & 2.155 & 2.175 & 18 & 1.1 & 2.072 & 2.116 & 56 & 0.79 \\
\hline $\begin{array}{l}150 \text {-vacuum } \\
\text { amorphous }\end{array}$ & 300 & 2.166 & 2.263 & 21 & 4.6 & 2.102 & 2.118 & 57 & 0.28 \\
\hline $\begin{array}{l}150 \text {-vacuum } \\
\text { amorphous }\end{array}$ & 400 & 2.183 & 2.335 & 21 & 7.2 & 2.083 & 2.115 & 57 & 0.56 \\
\hline Belt amorphous & 350 & 2.259 & 2.341 & 21 & 3.9 & 2.098 & 2.133 & 57 & 0.61 \\
\hline Belt amorphous & 400 & 2.108 & 2.137 & 21 & 1.4 & 2.090 & 2.105 & 57 & 0.26 \\
\hline Belt amorphous & 425 & 2.128 & 2.254 & 47 & 2.7 & 2.094 & 2.121 & 58 & 0.46 \\
\hline Belt amorphous & 450 & 2.093 & 2.185 & 22 & 4.2 & 2.081 & 2.098 & 57 & 0.30 \\
\hline III & 200 & 2.037 & 2.047 & 28 & 0.36 & 2.048 & 2.086 & 21 & 1.8 \\
\hline III & 250 & 2.045 & 2.052 & 30 & 0.23 & 2.053 & 2.101 & 21 & 2.3 \\
\hline III & 300 & 2.039 & 2.044 & 28 & 0.18 & 2.048 & 2.065 & 21 & 0.8 \\
\hline III & 300 & 2.054 & 2.076 & 22 & 1.0 & 2.049 & 2.080 & 21 & 1.5 \\
\hline III & 350 & 2.037 & 2.055 & 21 & 0.85 & 2.053 & 2.081 & 21 & 1.3 \\
\hline III & 400 & 2.041 & 2.048 & 27 & 0.26 & 2.052 & 2.090 & 21 & 1.8 \\
\hline III & 400 & 2.036 & 2.050 & 21 & 0.66 & 2.046 & 2.101 & 21 & 2.6 \\
\hline III & 450 & 2.049 & 2.072 & 27 & 0.85 & 2.039 & 2.080 & 21 & 1.9 \\
\hline
\end{tabular}

(a) The hydrated $\mathrm{UO}_{3}$ samples were dried at $300 \mathrm{C}$ before reduction to $\mathrm{UO}_{2}$. 
(5) The reactivity of $\mathrm{UO}_{3}$ towards hydration increases with increasing nitrogen content. For a given nitrogen content, amorphous $\mathrm{UO}_{3}$ has a higher hydration reactivity than crystalline Type III $\mathrm{UO}_{3}$.

(6) The change in the oxygen-to-uranium ratio of $\mathrm{UO}_{2}$ on exposure to air (measured after the first day) varies inversely with nitrogen content of $\mathrm{UO}_{3}$.

(7) The activity of $\mathrm{UO}_{2}$ may be increased by leaching or hydrating crystalline Type III $\mathrm{UO}_{3}$ or by leaching amorphous $\mathrm{UO}_{3}$, but is decreased by hydration and dehydration of amorphous $\mathrm{UO}_{3}$ prior to reduction.

\section{ACKNOWLEDGMENT}

The authors wish to express their appreciation to Mr. A. E. Ruehle and Dr. Carl Kuhlman of Mallinckrodt Chemical Works for supplying materials and their continued interest and invaluable discussions during the course of this work.

\section{REFERENCES}

(1) Bridge, J. R., Melton, C. W., Schwartz, C. M., and Vaughan, D. A., "Thermal Decomposition of U ranyl Nitrate Hexahydrate", BMI-1110 (July 12, 1956).

(2) Katz, J., and Rabinowitz, E., The Chemistry of Uranium, McGraw-Hill Book Company, Inc., New York (1951).

(3) Vaughan, D. A., Bridge, J. R., Allison, A. G., and Schwartz, C. M., "Processing Variables, Reactivity, and Sinterability of Uranium Oxides", to be published in Industrial and Engineering Chemistry.

(4) Barber, E. J., ORNL, private communication.

(5) Mallinckrodt Chemical Works, private communication.

$\mathrm{DAV}: \mathrm{JRB}: \mathrm{CMS} / \mathrm{mln}:$ ijs 